\title{
Damage potential and control measures of Necrobia rufipes (De Geer) (Coleoptera: Cleridae) on dry fish with plant materials
}

\author{
H. Ahmed ${ }^{1 *}$, K.N. Ahmed ${ }^{2}$, N. P. Khanom ${ }^{1}$ and P. Noor ${ }^{2}$ \\ ${ }^{1}$ BCSIR Laboratories, Bangladesh Council of Scientific and Industrial Research (BCSIR), Qudrat-i-Khuda Road, \\ Dhaka-1205 \\ ${ }^{2}$ Dhaka College, Dhaka
}

\begin{abstract}
As a source of high protein content, fish is one of the major categories of foods consumed by human beings. In Bangladesh, fish provides the main and the cheapest source of animal protein in the diet of all walks of people. The process of drying and salting have been practised for fish preservation through centuries. Feeding by the larvae and adults of Necrobia rufipes (De Geer) causes quantitative loss of dried or cured fish and also leads to fragmentation and to quality losses and contamination by insects' bodies and cast skins. In our present study, about $20 \%$ damage was caused by $N$. rufipes in a storage period of six months (April to September). For preservation of dry fishes, five plant based materials namely Neem, Nishinda, Eucalyptus, Turmeric powder, Mehagoni and ash were evaluated. Each of the plant leaf powder at a concentration of $5 \mathrm{gm}$ was uniformly mixed with $50 \mathrm{gm}$ Punti dry fish and placed in a Petri dish (10 cm diam.). Five newly emerged (0-24 hrs old) larvae and adults of $N$. rufipes were introduced into each Petri dish. Neem leaf powder exerted the best result followed by turmeric powder, Nishinda, ash, Eucalyptus and Mehagoni leaf powders for preventing the larval infestations. Turmeric powder exerted the best result followed by Neem, Euclyptus, Mehagoni, Nishinda leaf powder and mehagoni oil- cake for ceasing infestation of dry fishes.
\end{abstract}

Keywords: Necrobia rufipes; Damage; Control; Dry fish; Plant materials

\section{Introduction}

Losses by $N$. rufipes occur in two ways: by the actual feeding activity of larvae and adults and by cross-infestation resulting in a lowering of the value of other commodities in the field (Ashman, 1962). About 40\% flesh of the dried fish is lost annually during storage period (Fabian, 1975). A considerable amount of dried fish is lost in Bangladesh due to infestation by hide and copra beetles in storage conditions (Ahmed et. al., 1989). The copra or red-legged ham beetle is a cosmopolitan pest causing considerable damage to stored commodities such as copra (dried coconut), cheese, dried fish, ham and other products rich in protein contents (Nwana,1993). Damage by the feeding of the larvae is a serious problem in the storage of dry fishes for off-season consumption and export purpose. Their presence on high value commodities such as dried fish, copra, ham or processed meat, etc. can lead to produce reduction and serious losses (Hill, 1992). Insect infestation with dry fishes caused an increase in the anti- nutritional factors such as phytic acid, trypsin inhibitor activity and crude fibre as well as a decrease in starch and protein contents of stored produce. Although many synthetic chemicals are effective against the pests of many stored products, the general use of such chemicals to protect stored fish has been hampered due to health hazards, higher costs and less susceptibility of dermestid larvae (Amusan and Okorie, 2002; Odeyemi et. al., 2000). The need to protect smoked fish from pest attack is suggested because dry fish plays a prominent role during the hunger gap period between the first rains and first harvest. Besides, dry fish commodities are the cheapest and most accessible sources of animal proteins in situations of emergency for the distressed people in natural calamities. Thus, this study is aimed at searching for natural preservation methods which are not only safe to consumers but are also cheaper and easily accessible in protecting the highly valuable and popular commodities like dry fishes in the tropics.

\section{Materials and methods}

$N$. rufipes is a noxious insect pest of freshwater dry fishes, namely Punti, Chela, Kholisa, Chanda, Tengra, Kakila, Balia, prawn, Shingi, Taki, Chapila, Mola etc. This insect was collected from different local markets and dry fish stores

\footnotetext{
*Corresponding author. e-mail: knahmed2010@yahoo.com
} 
of different regions of Bangladesh. Collection sites were Bhairab Bazar, Kisoreganj, Birishiri, Netrokona, Rajshahi, Rangpur and local markets, viz. Kawran Bazar, Hatirpool Bazar and New market of Dhaka city. During this survey temperature, relative humidity, sunshine, rainfall, etc. were recorded.

Insect specimens were collected with the help of an aspirator and also by hand- picking method from the dry fish containers such as bamboomade basket (Tukri) and gunny bags. These specimens were kept in glass vials and Petri dishes.

The initial sources of $N$. rufipes were naturally infested dry fishes and dry fish market at Kawran Bazar. Several males and females of $N$. rufipes thus obtained were mass reared in plastic culture jars covered with muslin cloth at room temperature and relative humidity. The Petri dishes for experimental use were disinfected using the standard procedure by heat treatment in an oven at $70^{\circ} \mathrm{C}$ for 3-4 hours and then allowed to cool at room temperature. New generations of $N$. rufipes kept in different Petri dishes at an average room temperature of $29 \pm 2{ }^{\circ} \mathrm{C}$ and of $70 \pm 5 \%$ relative humidity were collected by removing adults of each insect species from a stock culture and placing them on fresh uninfected dry fish parent adults. Water was supplied with pieces of soaked cotton wool on Petri dish to increase relative humidity.

Five indigenous plant materials or biopesticides were collected for preservation of dry fishes in order to minimize insect pest infestation. The collected plant materials were whole and powdered leaves of Neem (Azadirachta indica L); Nishinda (Vitex negundo L.); Mehagoni (Swietenia mohago$n i$ L) (Mehagoni seed oil, Mehagoni seed dust and Mehagoni seed oil); Eucalyptus (Eucalyptus parallelus), turmeric powder (Curcuma longa L.). The plant leaves were collected and sun dried. Sun-dried leaves were grounded in a blender to make them powder. The dry fish preservation was done by using powdery form of the desired plant leaves and using liquid Mehagoni seed oil in different proportions to dry fish. Ash also was used to preserve dry fishes. Burnt paddy husk was the source of ash.

Each of the plant leaf powder at a concentration of $5 \mathrm{gm}$ was uniformly mixed with the body of 50 gm punti dry fish and placed in a Petri dish (10 cm diam.). Five newly emerged (0$24 \mathrm{hrs}$ old) larvae of $N$. rufipes were introduced into each Petri dish.

On the other hand, five newly emerged (0-24 hrs old) larvae of $N$. rufipes were introduced into each Petri dish. This experiment determined the effect of plant materials on the longevity of larvae and adults of $N$. rufipes. Wet cotton wool was supplied in each Petri dish to prevent dehydration. A control experiment was maintained consisting of the same number of insects exposed to the untreated dry fishes. Each treatment was replicated for 3 times. Longevity of the treated insects was recorded every 24 hrs for 31 days. Daily regular observations were made until adult mortality completion.

Another experiment was conducted using mehagoni seed oil on adult $N$. rufipes. Mehagoni seed oil at concentrations of $0.25,0.5$ and $1 \mathrm{ml}$ was thoroughly sprayed onto the body of 50 gm of punti dry fish, air dried for 2-3 hrs and placed in a Petri dish (10 cm diam.). Fifteen newly emerged adults (0 24 hrs old) of $N$. rufipes were introduced into each Petri dish and mortality was recorded.

All the experiments were conducted in the laboratory at $28 \pm$ $2^{\circ} \mathrm{C}$ and of $85 \pm 5 \%$ R.H. The effect of treatments on larva and adult Necrobia rufipes was analyzed by Duncan's Multiple Range Test (DMRT). ANOVA was done using Microsoft Excel Programme.

\section{Result and discussion}

About 20\% damage was caused by $N$. rufipes in a storage period of six months (April to September). The names, location and pest occurrence of popular fresh water dry fishes during survey period are given in Table I.

Effect of plant materials and ash on longevity of larva $N$. rufipes

Each of the plant leaf powder at a concentration of 5 gm was uniformly mixed with the body of 50 gm punti dry fish and placed in a Petri dish (10 cm diam.). Five newly emerged (0$24 \mathrm{hrs}$ old) larvae of $N$. rufipes were introduced into each Petri dish. Wet cotton wool was supplied in each Petri dish to prevent dehydration. A control experiment was maintained consisting of the same number of insects exposed to the untreated dry fishes. Each treatment was replicated for 3 times. Longevity of treated insects was noted every $24 \mathrm{hrs}$ for 31 days. Daily regular observations were made until larval mortality completion (Table II).

The effect of treatments on adult $N$. rufipes was statistically analyzed (ANOVA, LSD and DMRT). 
Table I. Pests of popular dry fishes of Bangladesh

\begin{tabular}{|c|c|c|c|c|c|}
\hline Sl.No. & $\begin{array}{l}\text { Name of the dry } \\
\text { fishes collected. }\end{array}$ & Locality & $\begin{array}{l}\text { Dominant insect } \\
\text { pests recorded }\end{array}$ & $\begin{array}{l}\text { Rate of } \\
\text { infestation }\end{array}$ & $\begin{array}{l}\text { Part } \\
\text { infested }\end{array}$ \\
\hline \multirow[t]{2}{*}{1} & Punti & & & & \\
\hline & (Puntius ticto) & Hatirpool Bazar, Dhaka. & N. rufipes & Severe & Head and thorax \\
\hline 2 & Chanda (Pampus sp.) & New market, Dhaka. & N.rufipes & Severe & Head \\
\hline \multirow[t]{2}{*}{3} & Prawn & & & & \\
\hline & (Penaeus monodon) & Kawran Bazar, Dhaka. & N. rufipes & Severe & Head, thorax and abdomen. \\
\hline \multirow[t]{2}{*}{4} & Mola & & & & \\
\hline & $\begin{array}{l}\text { (Amblypharyngodon } \\
\text { mola) }\end{array}$ & Netrokona (Birishiri) & $N$. rufipes & Medium & Head and abdomen. \\
\hline 5 & $\begin{array}{l}\text { Khalisha } \\
\text { (Colisa fasciatus) }\end{array}$ & $\begin{array}{l}\text { Bhairab Bazar, } \\
\text { Kishoregonj }\end{array}$ & $\begin{array}{l}\text { N. rufipes \& } \\
\text { D. maculatus }\end{array}$ & Severe & Head and thorax \\
\hline 6 & $\begin{array}{l}\text { Chapila } \\
\text { (Gadusia chopra) }\end{array}$ & Kawran Bazar,Dhaka & $\begin{array}{l}\text { N. rufipes \& } \\
\text { D. maculatus }\end{array}$ & Severe Head & and thorax \\
\hline 7 & Chela (Rohtea sp.) & Bhairab Bazar & N. rufipes & Medium & Head \& thorax. \\
\hline 8 & $\begin{array}{l}\text { Taki } \\
\text { (Channa punctatus) }\end{array}$ & New Market, Dhaka & $\begin{array}{l}\text { N. rufipes \& } \\
\text { D. maculatus }\end{array}$ & Severe & Head \\
\hline 9 & $\begin{array}{l}\text { Tengra } \\
\text { (Mystus cavasius) }\end{array}$ & Rangpur & $\begin{array}{l}\text { N. rufipes \& } \\
\text { D. maculatus }\end{array}$ & Medium & Head \& thorax \\
\hline 10 & $\begin{array}{l}\text { Shole } \\
\text { (Channa striatus) }\end{array}$ & Natore, Rajshahi. & N. rufipes & Minimum & Head \& thorax \\
\hline 11 & $\begin{array}{l}\text { Kakila } \\
\text { (Xenentodon cancila) }\end{array}$ & Rangpur & N. rufipes & Medium & Head \& thorax \\
\hline 12 & $\begin{array}{l}\text { Balia } \\
\text { (Glossogbius giuris) }\end{array}$ & Natore, Rajshahi. & N. rufipes & Medium & Head \\
\hline 13 & $\begin{array}{l}\text { Tara Baim } \\
\text { (Macrognathus } \\
\text { aculeatus) }\end{array}$ & Kawran Bazar, Dhaka. & Nil & - & - \\
\hline
\end{tabular}

Table II. Effect of different plant materials on the longevity of larva $N$. rufipes (days)

\begin{tabular}{|c|c|c|c|c|c|c|}
\hline \multirow[t]{2}{*}{ Treatment } & \multirow{2}{*}{$\begin{array}{c}\text { Weight of } \\
\text { plant material }(\mathrm{gm})\end{array}$} & \multicolumn{4}{|c|}{ Longevity of adult } & \multirow[t]{2}{*}{ Mean \pm S.D. } \\
\hline & & Control & $\mathrm{R} 1$ & $\mathrm{R} 2$ & $\mathrm{R} 3$ & \\
\hline Neem leaf powder & 5 & 27 & 9 & 10 & 12 & $10.33 \pm 1.53$ \\
\hline Nishinda leaf powder & 5 & 27 & 16 & 15 & 17 & $16.0 \pm 1.0$ \\
\hline Eucalyptus leaf powder & 5 & 27 & 18 & 19 & 20 & $19.0 \pm 1.0$ \\
\hline Turmeric powder & 5 & 27 & 17 & 16 & 15 & $16.0 \pm 1.0$ \\
\hline Mehgoni leaf powder & 5 & 27 & 30 & 30 & 30 & $30.0 \pm 0.0$ \\
\hline Ash & 5 & 27 & 16 & 17 & 16 & $16.33 \pm 0.58$ \\
\hline
\end{tabular}




\section{Effect of plant materials on longevity of adult $N$. rufipes}

Each of the plant leaf powder at a concentration of 5 gm was uniformly mixed with the body of 50 gm Punti dry fish and placed in a petri dish (100 mm diam.). Five newly emerged (0-24 hrs old) adults of $N$. rufipes were introduced into each Petri dish. Wet cotton wool was supplied in each Petri dish to prevent dehydration. A control experiment was maintained consisting of the same number of insects exposed to the untreated dry fishes. Each treatment was replicated for 3 times. Longevity was recorded every $24 \mathrm{hrs}$ for 31 days. Daily regular observations were made until adult mortality completion (Table III). es have been given in Table I. Treatments had significant effects on various parameters of $N$. rufipes (Tables II, III and IV).

The powders of Eucalyptus, Neem, Nishinda, and Mehagoni leaves, Turmeric powder, Mehagoni oil-cake, Mehagoni fruit powder, and ash more or less worked as surface protectants against $N$. rufipes. Reduced oviposition by the beetles on the treated dry fishes and the consequent lower larval and adult emergence reported in the studies might be as a outcome of high adult mortality caused by the botanicals. It is evident from the statistical analysis that turmeric powder exerted the best result in terms of control followed by Neem

Table III. Effect of different plant materials on the longevity of adult $\mathrm{N}$. rufipes

\begin{tabular}{lcccccc}
\hline Treatment & Weight of & \multicolumn{3}{c}{ Longevity of adult } & Mean \pm S.D. \\
& plant material $(\mathrm{gm})$ & Control & R1 & R2 & R3 & \\
\hline Mehgoni oil cake & 5 & 31 & 23 & 23 & 22 & $22.67 \pm 0.58$ \\
Mehgoni seed dust & 5 & 31 & 17 & 17 & 16 & $16.67 \pm 0.58$ \\
Neem leaf powder & 5 & 31 & 17 & 8 & 12 & $12.3 \pm 4.51$ \\
Nishinda leaf powder & 5 & 31 & 26 & 16 & 21 & $21.0 \pm 5.0$ \\
Eucalyptus leaf powder & 5 & 31 & 6 & 24 & 15 & $15.0 \pm 9.0$ \\
Turmeric powder & 5 & 31 & 3 & 8 & 7 & $6.0 \pm 2.65$ \\
\hline
\end{tabular}

The effect of treatments on adult $N$. rufipes was statistically analyzed (ANOVA, LSD and DMRT).

\section{Effect of mehagoni seed oil on the adult $N$. rufipes}

Mehagoni seed oil at concentrations of $0.25,0.5$ and $1 \mathrm{ml}$ was thoroughly sprayed onto the body of 50 gm of punti dry fish, air dried for 2-3 hrs and placed in a petri dish $(10 \mathrm{~cm}$ diam.). Fifteen newly emerged adults (0 - $24 \mathrm{hrs}$ old) of $N$. rufipes were introduced into each Petri dish and mortality was recorded (Table IV).

The impact of leaf powders and ash on the longevity of larval $N$. rufipes was analyzed by ANOVA. Pests of dried fish leaf powder, Eucalyptus leaf powder, Nishinda leaf powder and Mehagoni oil cake.

Sowunmi (1982) reported that insect infestation caused an increase in the anti-nutritional factors such as phytic acid, trypsin inhibitor activity and crude fibre as well as a decrease in starch and protein contents of stored produce. It is evident that the application of the plant materials and other ingredients prevented pest occurrence during storage. Unprotected fish (control) became unhygienic and therefore unfit for human consumption. The results obtained in the study are indicative of the potentials of plant materials in preserving the quality and quantity of freshwater dry fishes. Much more comprehensive research is very much to be solicited in this regard. 
Table IV. Effect of Mehgoni seed oil on adult $N$. rufipes

\begin{tabular}{lcccc}
\hline Concentration (ml) & $\begin{array}{c}\text { Weight of dry } \\
\text { fish (gm) } \mathrm{m}\end{array}$ & $\begin{array}{c}\text { Initiation of ortality } \\
\text { after treatment (minutes) }\end{array}$ & $\begin{array}{c}\text { No. of N. rufipes } \\
\text { treated }\end{array}$ & $\begin{array}{c}\text { Completion of } \\
\text { mortality after } \\
\text { treatment (minutes) }\end{array}$ \\
\hline 0.25 & 50 & 5 & 15 & 15 \\
0.5 & 50 & 5 & 15 & 20 \\
1 & 50 & 1 & 15 & 5 \\
\hline
\end{tabular}

*Data based on 15 observations

\section{References}

Alam MS (2004), Effect of gamma radiation on the developmental stages of $N$. rufipes (De Geer) infesting stored dry fishes. Univ. J. Zool., Rajshahi Univ. 23: 61- 64 .

Akinwumi FO, Fasakin EA and Adedire CO (2006), Progeny inhibiting effect of four plant products against the leather beetle and the copra beetle on smoked African mudfish. J. Bio-Sci., 6: 1023- 1028.

Akinwumi FO, Adedire CO and Fasakin EA (2007), Assessment of some plant derived insecticides on the organoleptic properties of catfish, Clarias gariepinus Burchell. J. Fish. Aquatic Sci. 2: 403- 409.

Ahmed KN (2009), Use of biopesticide in the suppression of major insect pests of dry fishes in Bangladesh. Final Report Submitted to the Ministry of Science and Information and Communication Technology, GOB, Dhaka. 19 pp.

Ahmed M, Bhuiya AD, Alam MS and Hud SMS (1989), Radiation preservation of food and fishery products. IAEA Technical Reports Series. No. 303: 125-139.

Amusan AAS and Okorie TG (2002), The use of Piper guineense fruit oil (PFO) as protectant of dried fish against Dermestes maculatus (De geer) infestation. Global J. Pure Applied Sci., 8: 197- 201.

Ashman F (1962), Factors affecting the abundance of the copra beetle, Necrobia rufipes (De Geer) (Coleoptera: Cleridae). Bull. Ent. Res. 53: 671-680.

Begum A, Khan HR and Shahriar ML (1997), Seasonal fluctuation of insects infesting the dry fishes in a market of
Dhaka city. J. Asiat. Soc. Bangladesh, Sci. 23: 315318.

Blatchford SM (1962), Insect infestation problems with dried fish. Trop. Stored Prod. Inf., 4: 112- 128.

Carvalho LML, Thyssen PJ, Linhares AX and Palhare FAB (2000), A checklist of arthropods associated with pig carrion and human corpses in Southeastern Brazil. Mem. Inst. Oswaldi Cruz., 95(1): 135-138.

Cotterell GS (1952), The insects associated with export produce in southern Nigeria. Bull. ent. Res., 43 : 145-152.

Fabian NGO (1975), Some aspects of the biology of Dermestes maculatus (De Geer) (Coleoptera: Cleridae) in dried fish. J. stored prod. Res. 11: 25-31.

Gredilha R and Lima AF (2007), First record of N. rufipes (De Geer, 1775)(Coleoptera ; Cleridae) associated with pet food in Brazil. Braz. J. Biol, 67: 187.

Haines CP (1984), Biological methods for integrated control of insects and mites in tropical stored products. Trop. Stored Prod. Inf. 48: 17- 25.

Hill DS (1992), Pests of stored products and their control. CBS Publishers and Distributors, Shahdhara, Delhi 110032, India, 274 pp.

Khan MAA and KhanYSA (2001), Insect infestation and preventive measures in dry fish storage of Chittagong, Bangladesh. Online Jour. Biol. Sci., 1: 963- 965.

Nowsad AKMA (2005), Low-cost processing of Fish in costal Bangladesh.GOB/UNDP/FOA Project: BGD/97/017. 
Nwana IE (1993), A survey of storage Coleoptera which attack dried cocoyam chips in Nigeria. J. Stored Prod. Res. 29: 95- 98.

Saha AK and Shahjahan RM (1998), Effects of Neem and radiation on the larvae of hide beetle, Dermestes maculatus De Geer (Coleoptera: Dermestidae) in dried fish. Bangladesh J. Zool. 26: 7-11.

Toye SA (1970), Studies on the humidity and temperature reaction to Dermestes maculatus Deg. (Col. : Dermestidae) with reference to infestation in dried fish in Nigeria. Bull. Ent. Res. 60: 23-31.
Taylor RWD and Proctor DL (1979), The infestation of dried fish by Dermestes sp. in Africa and appropriate control measures. Paper presented at UNIDO workshop on Appropriate Technology, Nairobi.

Walker DJ (1987), A review of the use of contact insecticide to control post- harvest insect infestation of fish and fish products. FAO Fish Circ., 804: 19.

Received: 05 August 2010; Revised: 05 August 2012; Accepted: 03 September 2012. 